\title{
BOARD CAPITAL AND BANK EFFICIENCY: INSIGHT FROM VIETNAM
}

\author{
Maria KONTESA ${ }^{1 *}$, Esmie Obrin $\mathrm{NICHOL}^{2}$, Jia-Sing BONG ${ }^{2}$, Rayenda Khresna BRAHMANA(D2 \\ ${ }^{1}$ Universitas Widya Dharma, Pontianak, 78243, Indonesia \\ ${ }^{2}$ Faculty of Economics and Business, Universiti Malaysia Sarawak, Kota Samarahan, 94300, Malaysia
}

Received 23 September 2019; accepted 10 February 2020

\begin{abstract}
This study investigates the role of board capital on bank's efficiency for a sample of 45 banks in Vietnam over 2011-2015. Using robust panel regression, we find board capital is important in making Vietnamese bank efficient even after controlling its endogeneity issue. This study further documents that networking capital and experience capital are the important factors, but not education for bank efficiency. The findings of this research contribute to the entrenchment hypothesis in agency theory, where networking and experience can be the bargaining power for manager (agent) in securing their compensation. It also contributes to human capital theory and resource base view theory where it shows networking and experience are stratetic human capital resources for bank efficiency. The findings imply that shareholders should consider the networking and experience of board members during board elections. Future research may engage with the intervention of corporate governance monitoring or test it in other developing countries context.
\end{abstract}

Keywords: board capital, networking capital, education capital, experience capital, bank efficiency.

JEL Classification: G21, G32, M12.

\section{Introduction}

Does directors' competency affect organization efficiency? Surprisingly, there is little evidence about the answer to this question as it is rarely found empirical research about the relationship between directors' competency and organization effectiveness. Most research emphasizes on the role economies of scale of a firm on organization efficiency, for example, the effect of capital structure (Margaritis \& Psillaki, 2007), size (Moutsianas \& Kosmidou, 2016), financial network (Silva et al., 2016), or income (Alhassan, 2015). This is quite intriguing considering Basel Accord III of BIS regulation and Sarbanes-Oxley Act 2002 address the importance of board competency in consolidating bankfirm performance. Empirical research supports this notion by documenting the benefit of financial knowledge and expertise for the organization's contingency (e.g., Karamanou \& Vafeas, 2005; Kim et al., 2014).

Theoretically, the seminal proposition of "Human Capital Theory" from Becker (1964) suggests the productivity of director depends on a broad range of human capital attributes. Intriguingly, economics and management literatures have primarily centered on the agency issue such as the incentives as the key factor of productivity. If any, it is more on survey research design (e.g. Harris et al.,
2015) which is more on testing a perception, or competency practices (e.g. Reeb \& Zhao, 2013). Building on this research gap, this research aims to empirically investigate the effect of those board competencies on organization efficiency, especially, the banking industry.

The main rationale of this research lays on the contestation between human capital theory and agency theory. Board capital, the human capital/competency of board of directors, is important to shareholders because they have few options for poor decision-making consequence due to limited ability or skill. However, choosing capable directors in a congested labour market is hard to do as there is no consensus as to which type of capabilities fit the organization's needs (Dalton et al., 1998; Rosenbusch et al., 2011; Wang et al., 2011). In contrast, the legal system relatively supports and safeguards the incapability of directors, and shareholders-government hardly sues or prosecutes directors for board errors due to misconduct or conflict of interest (Hermalin \& Weisbach, 2006).

In the context of banking industry, the competency needed is set even higher. This is due to the different banks' nature of business from other industries. Empirical findings such as Liao et al., (2007) show how competency management needed in bank is different from

${ }^{\star}$ Corresponding author. E-mail: mariakontesa80@yahoo.com 
other industries. This condition is strengthened by the new regulation from Basel III BIS which clearly states the importance of competency from board members for the bank's organization and management of risk. Taking this framework into a developing country would give contradicting point of view. A developing country generally has relatively low human development, and is newly liberalized compared to developed country. Hiring top talent from a developed country is viewed as full liberalization and "westernization". Many central banks in developing countries even restrict or disallow the use of expatriate in their banking industry. Certain scholars even argue there is no causality between education or experience on bank performance (refer to Van der Sluis et al., 2005). Therefore, it is interesting to test the role of human capital on bank efficiency within a developing country context like Vietnam.

The banking sector of Vietnam has contributed a large percentage to the increase of Vietnam's GDP since its open-economy policy in 1990s. However, Vietnam started to face bank efficiency issues since then. Hookway and Frangos (2012) stated that although Vietnam is listed as an emerging market, Vietnam is now losing its glow due to the piles of bad loans and financial crisis, and the primary task for Vietnam is to repair the beleaguered banking system. These bad loans and the financial turbulances have made the efficiency of Vietnam banks' decrease. Interestingly, the human development in Vietnam also faced low growth from 0.622 of HDI value in 2011 to 0.683 of HDI value in 2015 . The stricter regulation and bad corporate governance monitoring in choosing board directors of $\mathrm{Vi}$ etnamese banks may give interesting insight into the association between board capital and bank efficiency. The pertinent question remains: Does the board capital signify the efficiency of Vietnamese banks?

Vietnam offers a unique environment for investigating the effect of board capital on bank efficiency for several reasons. First, the high education level, networking, and experience among Vietnamese banks' directors would act as a good platform for a more detailed consideration of this topic. This is followed by Vietnam has an interesting institution setting to study the effect due to its less developed banking industry. Lastly, this research may obtain different opinions from the literature of this research area through the prevalence of leadership capability and bank's efficiency in the context of developing countries like Vietnam.

In summary, this research aims to investigate the role of board capital on bank efficiency. We also aim to reveal which board capital dimensions have significant effect on the efficiency of Vietnamese banks. It may also draw a contention about human capital theory and agency theory in the context of banking industry. We replicate the method developed by Reeb and Zhao (2013), and later modified by Brahmana et al. (2018), in which we use comprehensive measure of board capital. Different from previous research, this study tests the effect of board capital on bank's efficiency instead of non-banking or accountingrelated issue. We also follow previous research in bank efficiency such as Miller and Noulas (1996), Sufian (2007), and Silva et al. (2017) in constructing the measure. The detail is explained in Section 3.

The contribution of the study is threefold. First, this study adds to the understanding of board capital effect on bank's efficiency for a small emerging market. Second, this study documents the empirical findings of certain human capital that may significantly affect bank efficiency. In other words, principal (shareholders-government) may emphasize competency requirement into certain dimensions such as experience and networking, but not education. Lastly, we further establish the application of human capital theory in alignment with agency theory in the context of the banking industry.

This paper is outlined as follow. The next section addresses the literature review and research framework on board capital and bank's efficiency. Section 3 describes the method including its data. Section 4 documents the findings and discusses the results. Section 5 concludes.

\section{Literature review}

This research is different from other research papers in three ways. First, most human capital research employed with survey research design, and captured only the perception of managers. Earlier studies on board capital were mostly conducted for developed countries, and nonbanking industries. Moreover, majority of those research findings emphasised on investigation of the bank performance instead of bank efficiency. This section reveals the theoretical arguments about those issues and develop the hypothesis based on prior knowledge.

\section{Theoretical argument}

Our research framework is built from the disagreement of three major theories in economics and business: (1) knowledge transfer theory, (2) human capital theory, and (3) agency theory. In the perspective of knowledge transfer theory, knowledge within organization should have a transferring process from top management to their subordinates to achieve better organization dynamics (Smith, 2008). Firms with efficient knowledge transfer process will have higher chances to success (Hajidimitriou et al., 2012). It is in line with Deardorff and Djankov (2000) who found knowledge transfer has significant effect on increasing firm efficiency. Knowledge transfer theory when properly applied will increase the human capital of the board members, and they will make the good decision to enable the bank to operate efficiently and enhance the bank efficiency.

In the perspective of Becker's (1964) Human capital theory, competencies and capabilities of management are the resources in the process of achieving firm's objective. Human capital owned by management such as educational level, skills, values, and social assets may help to improve 
organization efficiency (Marimuthu et al., 2009). In other words, by upgrading educational level, the human capital of the board increases, thus, leading to better organization performance and efficiency. In the latter, findings from Parham and Heling (2015) and Micheal and Zaid (2014) confirm this postulation by documenting the positive relationship between human capital and organization performance.

Conversely, ageny theory views board capital as potential agency issue. For example, directors (agent) use their networking, experience and education as the bargaining power to retain their position in the firm (Finkelstein \& D’Aveni, 1994; Shi et al., 2017). Directors deemed their capital to be the important resource for the organization. They may request for higher compensation and it leads to higher agency cost (Maere et al., 2014). In short, agency theory surmises that high board capital might offer higher agency cost.

\section{Empirical evidence on board capital and bank efficiency}

Reeb and Zhao (2013) define human capital as the knowledge and skills of the directors gained from their working experience, while the social capital refers to the ability of the directors to communicate with individual or other social units. Human capital is a vital component of board capital that will allow the directors to manage their company's resources and to provide advice and counsel (Muttakin et al., 2018). It covers the capability to use the skills, experience, reputation, expertise and knowledge in order to accomplish mission, giving advice, as well as monitoring the operation of the business venture (Jeremias \& Gani, 2013; Shahrier et al., 2018).

Prior findings in economics and business have documented Banking and finance literatures show director capital plays an important role in business. For instance, Chen (2014) documents the evidence of how human and social capital of directors improves organization efficiency in term of information and resources. Jeremias and Gani (2013) and Lai et al. (2019) reported the positive relationship between board capital and bank performance. Meanwhile, Kauko (2008) argued that age and education will affect efficiency in complicated ways.

On a similar note, Reeb and Zhao (2013) stated that director capital is able to improve the disclosure quality through efficient board oversight. Haynes and Hillman (2010), Lai et al. (2019) said that board with high human and social capital can provide useful advice and counsel to the management of the bank or firm. In more recent findings, Shahrier et al. (2018) and Pucheta-Martínez and Gallego-Álvarez (2019) also argue that directors with a stronger human capital have better ability in enhancing performance of their organizations. Hence it can be concluded that the higher or the better the board capital, the better the bank efficiency. Therefore, the main hypothesis is as follow: $H_{1}$ : The higher the board capital, the better Vietnamese bank efficiency is.

\section{Methodology}

\section{Bank efficiency}

In this research, the dependent variable is bank efficiency. Bank efficiency is important as it can determine how effective and efficient the operation of the bank is. Efficiency can act as an indicator to determine the financial effect of the economy (Athanasoglou et al., 2008). Based on the research done by Kauko (2008), the most common type of efficiency used in the operation of the firm or bank is the cost efficiency. Bank efficiency is important as it can act as a risk management indicator and this can also help to attract more customers who are risk averse (Sufian, 2008).

In order to determine the bank efficiency, the Data Envelopment Analysis (DEA) approach is used. The DEA approach serves as a nonparametric method. Karlaftis (2004), used the DEA approach to test the efficiency of the transit system. The DEA approach is also used in determining the performance efficiency of banks (Diallo, 2018).

Sufian (2007) stated that the DEA method can be used to determine the overall effectiveness of banks. Furthermore, the non-parametric frontier-based DEA method is being used to determine the technical, pure technical and the scale efficiency (Sufian, 2009). This study employs the non-parametric frontier DEA approach with variable returns to scale (VRS) assumption to measure input-oriented technical efficiency of Malaysian banks. In this research, the valueadded approach efficiency is taken because the outcome of this research is more on financial performance. This is tally with the suggestion from Drake et al. (2006) and Sufian (2019). Value-added approach identifies those balance sheet categories as the output because it is significantly contributed to proportion of value added. Therefore, labour cost (personnel expenses/total assets), capital cost (total capital expenses/total fixed assets) and interest expenses are used as inputs producing outputs like deposit, loans, and investment. Therefore, an efficient bank is able to use fewer inputs such as interest expense, capital, and labor expense to produce more outputs such as deposit, loans, and investment.

We notice that there are other two approaches in measuring bank efficiency such as production approach (i.e., Hanafizadeh \& Marjaie, 2019), and financial intermediation approach (i.e., Leightner \& Lover, 1998; Hajer \& Anis, 2018). As mentioned above, this research chooses value added approach because it is closesly related to financial or balance sheet performance which is aligned with the human capital approach. Moreover, the main objective of the present study is not on the argument about bank efficiency but it is more on the application of human capital and agency theory on bank efficiency. Those two theories are more suitable with value added approach, and we leave the rest two approaches for future research.

It is also applied for the debate between non-parametric and parametric approach of efficiency. This study uses non-parametric approach instead of parametric approach. 
Bjurek et al., (1990) and Sharma et al. (1999) found that there is no significant difference of the results between parametric approach and non-parametric approach, or between stochastic frontier and frontier DEA. Moreover, this present study uses efficiency as the dependent variable and contests it with human capital factor. It is not a methodological or technical research paper about efficiency. Therefore, we also leave the debate between non-parametric and parametric approach of efficiency for future research.

\section{Model specification}

This study follows prior research on bank efficiency in constructing the baseline for the estimation model, whereas It is imperative to control bank's efficiency with non-performing loan (NPL), net interest margin (NIM), loan to deposit ratio (LDR), bank's size (SIZE), and age of bank (AGE) on bank efficiency model (Girardone et al., 2004; Sufian, 2008). To answer the main research objective, we introduce board capital (BC) into that baseline model as the main effect. Hence, the full model will be the independent variable plus the control variables as shown below:

$$
\begin{gathered}
E F F_{i t}=\beta_{0}+\beta_{1} E F F_{i t-1}+\beta_{2} N P L_{i t}+\beta_{3} N I M_{i t}+ \\
\beta_{4} L D R_{i t}+\beta_{5} S I Z E_{i t}+\beta_{6} A G E_{i t}+\beta_{7} B C_{i t}+\varepsilon_{i t} .
\end{gathered}
$$

$E F F$ is the bank efficiency. It is calculated using the DEA approach. NPL is the bank's non-performing loan, which is defined as the sum of borrowed money upon which debtors have not made their scheduled payments for at least 90 days (Sufian, 2008). NIM is net interest margin, which is a performance indicator of how successful a firm investment decisions are when compared to its debt situations (Sufian, 2008). It is calculated as the ratio of the difference between interest income and interest expense to total earnings. LDR is loan to deposit ratio. Size is the bank's size which is calculated by natural logarithm of total assets (Brahmana et al., 2018), and Age is the period of the bank establishment (Brahmana et al., 2019).

Board capital has three dimensions, which are education, networking and experience. Each dimension has its own items. There are six, one, and five items for networking, education, and experience, respectively. We follow Reeb and Zhao (2013) and later modified by Brahmana et al. (2019) in scoring each item of each dimension as shown in Table 1.

For the six items of networking capital (refer to Table 1), we did hand-collection from annual report, linkedin, RelSci, Bloomberg, and google analytic. We sum up the total value of each items from each bank in each year. Because several banks change their directors only after three years, we use quantile method to solve the variance issue. The example of the process is as follow: First, we sum up the total value of item no. 1 (Total current number of boards a director sits on during a given year, refer Table 1) in year 2014 for each bank. Then, we rank the total value for item no.1 from lowest to highest in year 2014. After that, we divide it into $20^{\text {th }}$ percentile group. Banks that fall into the first 20th percentile is given a score of "1", meanwhile, banks that fall into the last $20^{\text {th }}$ percentile (the highest) is given a score of " 5 ". We repeat this procedure for 2012 to 2015. We also repeat this procedure to other items of networking. At the end, each bank has value of 1 to 5 for each items in each year. The last procedure is calculating the average value from all items of

Table 1. Board capital item measurement (source: compiled from Reeb and Zhao (2013) and Brahmana et al. (2019))

\begin{tabular}{|l|l|l|}
\hline \multicolumn{3}{|c|}{ Developed indices to form a composite measure of total board capital } \\
\hline \multicolumn{1}{|c|}{ Networking or socializing of the board } & \multicolumn{1}{|c|}{ Education of the board } & \multicolumn{1}{c|}{ Experience capital of the board } \\
\hline $\begin{array}{l}\text { 1. Total current number of boards a } \\
\text { director sits on during a given year. }\end{array}$ & $\begin{array}{l}\text { 1. Total number of director } \\
\text { that obtain bachelor's degree, } \\
\text { master's degree, law degree or } \\
\text { medical degree, as well as a } \\
\text { doctoral degree. }\end{array}$ & $\begin{array}{l}\text { 1. Working history: the number of directors who } \\
\text { have been a partner in a law firm; have investment } \\
\text { consulting experience; accounting firm expertise; } \\
\text { academic experience. }\end{array}$ \\
\hline $\begin{array}{l}\text { 2. Total current number of nonprofit boards } \\
\text { a director sits on }\end{array}$ & $\begin{array}{l}\text { 2. Director information on professional certification } \\
\text { such as CPA, CFA or certified fraud examiner. }\end{array}$ \\
\hline $\begin{array}{l}\text { 3. Total number of corporate board } \\
\text { memberships / the total number of } \\
\text { commissioners }\end{array}$ & $\begin{array}{l}\text { 3. Number of positions higher than vice president } \\
\text { (Chemmanur \& Paeglis, 2005) that directors have } \\
\text { held during their lifetime. }\end{array}$ \\
\hline $\begin{array}{l}\text { 4. Number of non-profit boards that a } \\
\text { director has served on in the past but is } \\
\text { no longer a current member / the total } \\
\text { number of independent commissioners }\end{array}$ & $\begin{array}{l}\text { 4. Count of the number of firms with which the } \\
\text { directors have worked during their lifetime. }\end{array}$ \\
\hline $\begin{array}{l}\text { 5. Any current or prior government } \\
\text { position }\end{array}$ & & $\begin{array}{l}\text { 5. Others potential director characteristic such as } \\
\text { national-level honors and awards and membership } \\
\text { in professional or industrial association affiliations. }\end{array}$ \\
\hline $\begin{array}{l}\text { 6. Capture director information on } \\
\text { government board service which is } \\
\text { nominated by government agents. }\end{array}$ & & \\
\hline
\end{tabular}


each bank in a particular year. Because networking has six items, the average value from the six items in each year is the networking capital value. For example, Bank A in year 2012, falls into group $1,1,3,3,4$, and 4 for items no. 1, 2, $3,4,5$, and 6 respectively. The average value of networking is $2.67(16=1+1+3+3+4+4)$ This value is used as the data of measurement for regression process.

For experience capital, the procedure is the same. There are five items of experience capital (refer Table 1 ), and we repeated the same procedure like networking capital. We did hand-collection data from annual report, linkedin, Bloomberg, and Relsci, then score each item of experience. Again, each item for each bank will have total value for each year. Then, it is ranked according to $20^{\text {th }}$ percentile method. Each bank will have score 1 to 5 according to their percentile group. The average value from the five items is the experience value that used as the data of measurement for regression process.

However, the education capital is processed slightly different. Unlike the other two capitals, this education capital is a single item. Our first step is to assign a value for the education level of each board member in the bank. Firstly, we list out all board member for each bank in a particular year. Then, each board member highest education level was checked and was scored accordingly by referring to Table 2. The next procedure is to sum up all the score from all board member, and divided it by total board members. We then re-employ the $20^{\text {th }}$ percentile grouping. To avoid Gaussian bias, we standardize that mean value for each bank in each year. Finally, the board capital value is the average value from those three capitals (networking, experience, and education) for each bank in each year.

Table 2. Director educational level (source: compiled from Reeb and Zhao (2013) and Brahmana et al. (2019))

\begin{tabular}{|l|c|}
\hline \multicolumn{1}{|c|}{ Level of Education } & $\begin{array}{c}\text { Number } \\
\text { Represents }\end{array}$ \\
\hline Below the bachelor's degree & 1 \\
\hline Bachelor's degree & 2 \\
\hline $\begin{array}{l}\text { Bachelor's degree from QS 200 Top World } \\
\text { University }\end{array}$ & 3 \\
\hline Master degree & 4 \\
\hline Master degree from from QS 200 Top World & 5 \\
\hline Doctoral Degree & 6 \\
\hline Doctoral degree from QS 200 Top World & 7 \\
\hline
\end{tabular}

\section{Data}

We use annual reports downloaded from each bank's website and the Vietnam stock exchange to retrieve board capital and financial information for the years 2011 to 2015. Our initial sample covers the entire 125 Vietnamese banks, yet, most of those banks are representative offices or branches. Therefore, we exclude those representative offices and banks from our samples because it will not capture the comprehensive organization dynamics of a bank. We also remove any banks that have missing data throughout our research period. At the end, our final sample comprises 45 Vietnamese banks with the total pooled observations of 225 bank years over the period of 5 years with complete data. The sample is a combination of listed and non-listed bank, in which after we run the paired ttest and independent mean $t$-test to reveal the significant difference between listed and non-listed banks, the statistical results imply there is no significant difference between these two classes (listed and non-listed). This also answers the doubt in DEA benchmark approach in the banking research setting, wherein, we use almost all banks in Vietnam, listed and non-listed. As for the latter, size is treated as the control variable. We use linkedin, RelSci, Bloomberg, and google analytic to determine the networking and experience dimension of board member.

\section{Results and discussion}

\section{Descriptive result}

Table 3 describes the summary statistics for our sample of 45 banks across a five-year period (2011-2015). It discusses the descriptive of bank's efficiency, board capital, nonperforming loan (NPL), net interest margin (NIM), loan to deposit ratio (LDR), bank size as well as the bank age.

In regard to bank efficiency, it shows a maximum value of 1 and a minimum value of 0 . The mean and standard deviation are 0.3302 and 0.3404 , respectively. This implies that the average efficiency value in Vietnam is 0.3302 , which is far from the efficient value of 1 . Meanwhile, director capital shows a maximum value of 4.55 and a minimum value of 0.1 . A mean value of 3.2168 and overall standard deviation of 1.1293 shows a low board capital value for Vietnamese banks. The NPL, NIM, and LDR have anaverage value of $2.4 \%, 6.1 \%$, and $14.7 \%$, respectively. It is tally with the requirement of Vietnam central bank regulation.

Table 3. Descriptive statistics results

\begin{tabular}{|l|c|c|c|c|}
\hline \multicolumn{1}{|c|}{ Variable } & Mean & Std. Dev. & Min & Max \\
\hline Bank Efficiency & 0.3302 & 0.3404 & 0.0000 & 1.0000 \\
\hline Board Capital & 3.2168 & 1.1293 & 0.1000 & 4.5500 \\
\hline NPL & 0.0243 & 0.1212 & 0.0000 & 1.1620 \\
\hline NIM & 0.0606 & 0.6203 & 0.0000 & 9.3192 \\
\hline LDR & 0.147 & 0.8664 & -5.9626 & 5.3156 \\
\hline Bank Size & 0.9379 & 0.6677 & 0.0000 & 1.6302 \\
\hline Bank Age & 0.1549 & 0.1512 & 0.0000 & 0.6000 \\
\hline
\end{tabular}

For bank size and bank age, Table 3 shows it in natural logarithm value. Bank size has a minimum value of 0 and a maximum value of 1.6302 . The average value is 0.9379 and the standard deviation is 0.6677 . Lastly, the variable age has a minimum value of 0.6 and a maximum value of 0 , with mean value of 0.1549 and standard deviation of 0.1512 .

Table 4 shows the result for correlation matrix among the variables. It implies that board capital has significant 
Table 4. Correlation matrix

\begin{tabular}{|c|c|c|c|c|c|c|c|}
\hline & EFF & $\mathrm{BC}$ & NPL & NIM & LDR & SIZE & AGE \\
\hline EFF & 1.0000 & & & & & & \\
\hline \multirow{2}{*}{$\mathrm{BC}$} & $0.4239^{* * *}$ & 1.0000 & & & & & \\
\hline & $(0.0000)$ & & & & & & \\
\hline \multirow{2}{*}{ NPL } & 0.0391 & $0.1619^{* \star}$ & 1.0000 & & & & \\
\hline & $(0.5596)$ & $(0.0150)$ & & & & & \\
\hline \multirow{2}{*}{ NIM } & $0.1451^{* *}$ & 0.0186 & -0.0099 & 1.0000 & & & \\
\hline & $(0.0296)$ & $(0.7813)$ & $(0.8826)$ & & & & \\
\hline \multirow{2}{*}{ LDR } & $0.2535^{* * *}$ & $0.1106^{*}$ & -0.0376 & $0.3755^{* *}$ & 1.0000 & & \\
\hline & $(0.0001)$ & $(0.0978)$ & $(0.5749)$ & $(0.0000)$ & & & \\
\hline \multirow{2}{*}{ SIZE } & $0.6955^{* * *}$ & $0.6322^{*}$ & $0.1332^{* *}$ & 0.0483 & 0.0169 & 1.0000 & \\
\hline & $(0.0000)$ & $(0.0000)$ & $(0.0459)$ & $(0.4706)$ & $(0.8013)$ & & \\
\hline \multirow{2}{*}{ AGE } & $0.5552^{\star * *}$ & $0.4363^{* * *}$ & 0.1024 & 0.0631 & 0.0454 & $0.7002^{* * *}$ & 1.0000 \\
\hline & $(0.0000)$ & $(0.0000)$ & $(0.1256)$ & $(0.3462)$ & $(0.4979)$ & $(0.0000)$ & \\
\hline
\end{tabular}

correlation with bank efficiency. The correlation value is 0.4239 implying moderate correlation magnitude. This result is an early indication for the association. Other variables such as net interest margin (NIM), loan to deposit ratio (LDR), size, and age have the same conclusion wherein it has significant correlation with bank efficiency. The magnitude of correlation is small for NIM (0.1451) and LDR (0.2535), but strong correlation magnitude for size (0.6995) and age (0.5522). However, our findings document that non-performing loan (NPL) shows no significant correlation with small correlation value.

\section{Board capital and bank efficiency}

The full model is run under Fixed Effect panel regression. It controls the autocorrelation and heteroscedasticity issue by controlling its standard error under White's test. Then, we rerun the model under System GMM of Blundell and Bond (1998) to tackle the dynamic specification of the model due to endogeneity issue (Pedroni, 1996). Moreover, important modelling concerns related to fixed effects and endogeneity of regressors, are addressed while avoiding dynamic panel bias (Nickell, 1981).

Table 5 documents the board capital-bank efficiency estimation results. There is a slight difference between our fixed effect model and GMM model for our control variables. Non-performing loan (NPL), net interest margin (NIM), loan to deposit ratio (LDR), bank size (SIZE), and bank age (AGE) have contributed significantly to Vietnamese bank efficiency. This is in line with previous findings of Lartey et al. (2013) who surmises that economies of scale from bank are important factors in enhancing Vietnamese bank efficiency.

As for the main variable: board capital, both estimation models (Fixed effect and GMM) have similar conclusion. Board capital is shown to have a significant effect on bank efficiency at $5 \%$ significance level. This implies that higher board capital may induce the efficiency of Vietnamese banks. This is consistent with previous findings of
McDonald, Westphal, and Graebner (2008), Haynes and Hillman (2010), and Brahmana et al. (2018), that competency and capability such as networking, experience, and

Table 5. Board capital result. The regression is performed under robust Fixed Effect and System GMM panel regression. The figures stated are the coefficient values, except numbers in parentheses, which are standard error. The dependent variable is bank efficiency. The main effect is board capital, meanwhile, the control variables are non-performing loan (NPL), net interest margin (NIM), loan to deposit ratio (LDR), bank size, and Bank Age. ${ }^{\star},{ }^{* *}$, and ${ }^{\star * *}$ denotes the significance level at $10 \%, 5 \%$, and $1 \%$, respectively. $\operatorname{AR}(1)$ and $\operatorname{AR}(2)$ denote the Arellano Bond test for zero autocorrelation in first and second differenced errors, respectively. Sargan and Hansen are the

postestimation test for the overidentyfying restriction

\begin{tabular}{|l|c|c|}
\hline \multirow{2}{*}{ EFF (L1) } & Fixed Method & System GMM (BB) \\
\cline { 2 - 3 } & & $0.1841^{\star \star *}$ \\
\hline \multirow{3}{*}{ Board Capital } & $0.1366^{\star *}$ & $(0.0616)$ \\
\cline { 2 - 3 } & $(0.0621)$ & $0.0658^{\star *}$ \\
\hline \multirow{2}{*}{ NPL } & $-0.1668^{\star * *}$ & $(0.0254)$ \\
\cline { 2 - 3 } & $(0.0479)$ & $-0.1259^{\star *}$ \\
\hline \multirow{2}{*}{ NIM } & $0.0084^{\star * *}$ & $(0.0512)$ \\
\hline \multirow{2}{*}{ LDR } & $(0.0021)$ & $0.0571^{\star}$ \\
\hline \multirow{2}{*}{ Bank Size } & $0.0978^{\star * *}$ & $(0.0308)$ \\
\cline { 2 - 3 } & $(0.0381)$ & $0.0058^{\star}$ \\
\hline \multirow{2}{*}{ Bank Age } & $0.2288^{\star * *}$ & $(0.0339)$ \\
\hline & $(0.0628)$ & 0.0844 \\
\hline AR(1) & $0.5155^{\star *}$ & $(0.0785)$ \\
\hline AR(2) & $(0.2011)$ & $0.1102^{\star}$ \\
\hline Hansen & & $(0.0601)$ \\
\hline Sargan & & 0.028 \\
\hline
\end{tabular}


education are very important for bank operation. This confirms the human capital theory whereby better human capital leads to better organizational performance.

\section{Robustness Test: networking, experience, and education effects}

Table 5 above shows the significant role of board capital on bank efficiency. The above result, however, cannot show which dimension has a significant effect on bank efficiency. Therefore, we break down board capital into its three dimensions: networking, experience, and education, and re-run the estimation model, using the same panel regression procedure. Table 6 shows the results.

The conclusion for all control variables remain the same, except for net interest margin (NIM). The NPL, LDR, size, and age have significant effects on bank efficiency. NPL is the only variable with negative association implying the higher the credit default, the lower the bank efficiency.

Table 6 reports interesting findings. Only two out of three board capital dimensions have significant effect on bank efficiency. Networking has positive influence on bank efficiency at $5 \%$ significance level, indicating a bigger

Table 6. Board capital result in detail. The regression is performed under robust Fixed Effect and System GMM panel regression. The figures stated are the coefficient values, except numbers in parentheses, which are standard error. *, ${ }^{* *}$, and ${ }^{* *}$ denotes the significance level at $10 \%, 5 \%$, and $1 \%$, respectively

\begin{tabular}{|c|c|c|}
\hline Variables & Fixed Effect & System GMM (BB) \\
\hline \multirow{2}{*}{ EFF (L1) } & & $0.2253^{\star *}$ \\
\hline & & $(0.0943)$ \\
\hline \multirow{2}{*}{ Education } & 0.1369 & 0.1688 \\
\hline & $(0.0996)$ & $(0.1112)$ \\
\hline \multirow{2}{*}{ Networking } & $0.3034^{* *}$ & $0.2340^{* *}$ \\
\hline & $(0.1270)$ & $(0.1072)$ \\
\hline \multirow{2}{*}{ Experience } & $0.1212^{\star *}$ & $0.1408^{\star}$ \\
\hline & $(0.0606)$ & $(0.0730)$ \\
\hline \multirow{2}{*}{ NPL } & $-0.2896^{* * *}$ & $-0.3414^{\star * *}$ \\
\hline & $(0.0806)$ & $(0.0931)$ \\
\hline \multirow{2}{*}{ NIM } & $0.0798^{\star *}$ & 0.0670 \\
\hline & $(0.0376)$ & $(0.0431)$ \\
\hline \multirow{2}{*}{ LDR } & $0.1512^{* *}$ & $0.1623^{\star *}$ \\
\hline & $(0.0662)$ & $(0.0658)$ \\
\hline \multirow{2}{*}{ SIZE } & $0.3301^{* * *}$ & 0.3345 \\
\hline & $(0.1076)$ & $(0.2056)$ \\
\hline \multirow{2}{*}{ AGE } & $0.6472^{*}$ & 0.1461 \\
\hline & $(0.3611)$ & $(0.0930)$ \\
\hline $\operatorname{AR}(1)$ & & 0.027 \\
\hline $\operatorname{AR}(2)$ & & 0.351 \\
\hline Hansen & & 0.061 \\
\hline Sagan & & 0.064 \\
\hline
\end{tabular}

network may increase bank efficiency. Board members with high level of networking may improve the bank efficiency. Having networking with government, non-profit organization or public sector organization might improve the bank efficiency. It is tally with the findings from Chen et al. (2014), and Lin et al. (2016).

Table 6 also documents the significant contribution of experience on bank efficiency. The relationship is statistically significant at $5 \%$ level. Higher experience board member will improve the bank efficiency. Hence, experience from director's working history, professional standing, reputation, tenure of service, and number of other companies for which he has been elected as a board member give better strategic decision making, and may contribute out of the box ideas. This result is in line with Lin et al. (2014), and Carnegie (2016).

Interestingly, our findings show there is no significant effect of education on bank efficiency, be it an undergraduate degree, or a $\mathrm{PhD}$ degree, or a degree from any world top university. It may contribute to Basel III BIS that competency in bank management and risk is not related to the educational level of board members, specifically in the context of a developing country. This also signifies that the current educational system might not be in line with the competency needed for banks' operations. In summary, our findings are; first, board capital has significant effect on bank efficiency, as shown in Table 5. Second, as shown in Table 6, only experience capital and networking capital have significant effects on bank efficiency, but not educational capital.

\section{Discussion}

Our results show three important findings. First, it shows that board capital has positive effect on bank efficiency, implying higher board capital will boost Vietnam bank efficiency. Second, only networking and experience have significant effect on bank efficiency, but education level does not have any significant effect. This indicates that banks have to choose board members with higher networking and experience, rather than focus on their education level. Lastly, we eliminate the heterogeneity and endogeneity issue in the estimation variance by utilizing robust panel regression. Our findings can be generalized for Vietnamese banking industry and perhaps for other developing countries.

Overall, our research supports human capital theory where competency, or human capital, is an important factor for organization performance. Board capital covers the network, education, and experience of the board of directors. Good networking with various corporations and non-governmental bodies would help to support a bank in adversity. This has been proven by previous research (e.g. Faccio et al., 2006; Pesämaa \& Hair, 2007; Carney et al., 2011; Chung, 2011). Those mentioned studies document that good network generates healthy resources for the organization, and it makes organization become more efficient. Likewise, the board of directors with a proven 
track record and high experience is a competitive resource for the bank. Their know-how in handling and tackling complexity of bank operation allows to operate efficiently. It is consistent with the findings of Huhtala et al. (2014), and Boling et al. (2016).

Bank should know when to increase and decrease loanable funds to consumers in order to avoid high default risk. An increase in non-performing loans could increase the financial distress level of the banking institution. This is in line with prior research such as Elloumi and Gueyie (2001), Haynes and Hillman (2010), Hillman and Dalziel (2003), and Brahmana et al. (2019).

However, high educational background is not important for the banking industry. This is consistent with human capital theory, where in a labour market, most talents have similar educational level (Lee \& Law, 2017; Lopes De Melo, 2018). Therefore, it does not give any effect to the bank competitive resource. Binh and Giang (2012) argued that Vietnam's commercial bank managers do not act in the best interest of the shareholders. Thus, the divergence of goals and interests between the agents and principals unfortunately generate costs.

In terms of agency theory, the findings imply an important conclusion related to alignment. Jensen and Meckling (1976) and later confirmed by Allen and McAllister (2018) address compensation as a tool for alignment reducing agency cost. Our research shows that it is not necessary true, instead, shareholders (principal) may elect board member with high networking and high experience to have better efficiency for lower agency cost. If we look at in detail in Table 1, it shows that networking is actually related to corporate monitoring. Having high networking implies good monitoring. Previous research like Mustapha (2014) and Madison et al. (2016) surmise that effective number of board member and social networking among peers have significant effect to reduce agency cost resulting better performance.

Similar explanation is also found for how experience board member reduces the agency cost. Experienced board member usually has high tenure and has more comprehensive know-how in running bank. Therefore, this experienced board member tends to retain their reputation and usually aims for driving a good performance for company (Simsek, 2007; Hamori \& Koyuncu, 2015; Brahmana et al., 2019). This explains why having more experience capital will lead to better level of bank's efficiency.

Yet, our findings related to this agency cost needs further validation. Perhaps, high networking board member or high experience board member already has high compensation. This explain why by having those two capital awarding better performance. Another explanation is that board member with high networking or high experience may retain their reputation among the peers, hence, they tend to have alignment and reduce the agency cost. These two limitation will be an interesting platform for future research.

\section{Conclusions}

This study contests human capital theory and agency theory in the finance research setting. It examines the phenomenon of board capital importance in the banking industry, especially, within a developing country context. This study is motivated by the lack of attention given to this research area, especially in the banking industry. Our findings possibly lays the foundations for further research in this area in emerging markets with more focus on the institutional setting of each region. Our findings show the significant effect of board capital on Vietnamese bank efficiency. However, our detailed findings document only networking and experience dimensions to have significant contribution to bank efficiency.

This study adds to the existing economics and management literature on board capital - efficiency nexus. We adopted the model developed by Maere, Jorissen, and Uhlaner (2014) and introduced board capital which is developed by Reeb and Zhao (2013) and Brahmana et al. (2019) to the model. Our findings test a research framework that incorporates human capital and agency theory. We find that board capital is a significant factor for achieving efficiency by Vietnamese banks. In addition, our findings suggest that Vietnamese banks should focus more on their board members' experience and networking rather than their educational level. Having a politically connected director or highly experienced director is relatively much more important than having a doctoral degree director. This is consistent with prior research that shows the importance of political connection (Chen et al., 2014), tenure (Lin et al., 2014), reputation (Lin et al., 2016), and professional certification such FRM or CFA (Carnegie, 2016) for the bank's operation. Another contributing aspect of our study is that we use robust panel data approach that allows for assessing changes in capital level over time, and thus gives estimates that are more reliable.

However, all our findings need to be validated by further research on other emerging countries in order to verify some facts about certain common characteristics embedded in Vietnamese banking industry. The main limitation of this research is that it does not gauge the different effect of board capital on efficiency due to ownership expropriation and corporate governance factors. More in-depth insights can be gained for future research through other examinations such as the role of ownership structure, CEO publicity, corporate governance attributes, compensation, and founding-father directors.

As earlier mentioned above, the measure of efficiency has also another limitation where this current research applied value added approach combined with non-parametric of Data Envelope Analysis. Future research may tackle the issue of different board capital effect on efficiency if the approach is production approach or financial intermediation approach. Additionally, it will be interesting if future research examines this board capital - efficiency framework on Islamic banking framework. 


\section{Funding}

This research acknowledges the assistance from Universiti Malaysia Sarawak via MyRA special Grant (F01/SpMYRA/1680/2018).

\section{Author contributions}

Maria Kontesa was responsible on the introduction. Esmie Nichols was responsible for the flow and research gap. JiaSing Bong was responsible for data collection. Rayenda Khresna Brahmana was responsible for analysis. Maria Kontesa and Esmie Obrin Nichol were responsible for conclusion.

\section{References}

Alhassan, A. L. (2015). Income diversification and bank efficiency in an emerging market. Managerial Finance, 41(12), 1318-1335. https://doi.org/10.1108/MF-12-2014-0304

Allen, A., \& McAllister, B. (2018). CEO compensation and performance in US private foundations. Financial Accountability \& Management, 34(2), 117-132. https://doi.org/10.1111/faam.12150

Athanasoglou, P. P., Brissimis, S. N., \& Delis, M. D. (2008). Bankspecific, industry-specific and macroeconomic determinants of bank profitability. Journal of international financial Markets, Institutions and Money, 18(2), 121-136.

https://doi.org/10.1016/j.intfin.2006.07.001

Becker, G. S. (1964). Human capital. Columbia University Press.

Binh, D. T. T., \& Giang, H. T. H. (2012). Corporate governance and performance in Vietnamese Commercial Banks. Journal of Economics and Development, 14(2), 72-95.

https://doi.org/10.33301/2012.14.02.04

Bjurek, H., Hjalmarsson, L., \& Forsund, F. R. (1990). Deterministic parametric and nonparametric estimation of efficiency in service production: A comparison. Journal of Econometrics, 46(1-2), 213-227.

https://doi.org/10.1016/0304-4076(90)90056-Y

Blundell, R., \& Bond, S. (1998). Initial conditions and moment restrictions in dynamic panel data models. Journal of Econometrics, 87(1), 115-143. https://doi.org/10.1016/S0304-4076(98)00009-8

Boling, J. R., Pieper, T. M., \& Covin, J. G. (2016). CEO tenure and entrepreneurial orientation within family and nonfamily firms. Entrepreneurship Theory and Practice, 40(4), 891-913. https://doi.org/10.1111/etap.12150

Brahmana, R., Kontesa, M., \& Gilbert, R. E. (2018). Income diversification and bank performance: evidence from Malaysian banks. Economics Bulletin, 38(2), 799-809.

Brahmana, R., Ung, L. J., \& Kiu, J. S. (2019). Does board capital affect the corporate financial distress level? A study from Malaysia. Kasetsart Journal of Social Sciences, 40(3), 695-702.

Carnegie, G. D. (2016). The accounting professional project and bank failures: The case of the early 1890s Australian banking crisis. Journal of Management History, 22(4), 389-412. https://doi.org/10.1108/JMH-04-2016-0018

Carney, M., Gedajlovic, E. R., Heugens, P. P., Van Essen, M., \& Van Oosterhout, J. H. (2011). Business group affiliation, performance, context, and strategy: A meta-analysis. Academy of Management Journal, 54(3), 437-460.

https://doi.org/10.5465/amj.2011.61967812
Chen, H. L. (2014). Board capital, CEO power and R\&D investment in electronics firms. Journal of Corporate Governance, 22(5), 422-436. https://doi.org/10.1111/corg.12076

Chen, Y. S., Shen, C. H., \& Lin, C. Y. (2014). The benefits of political connection: evidence from individual bank-loan contracts. Journal of Financial Services Research, 45(3), 287-305. https://doi.org/10.1007/s10693-013-0167-1

Chung, H. F. (2011). Market orientation, guanxi, and business performance. Industrial Marketing Management, 40(4), 522533. https://doi.org/10.1016/j.indmarman.2010.12.008

Dalton, D. R., Daily, C. M., Ellstrand, A. E., \& Johnson, J. L. (1998). Meta-analytic reviews of board composition, leadership structure, and financial performance. Strategic Management Journal, 19(3), 269-290.

https://doi.org/10.1002/(SICI)1097-0266(199803)19:3<269:: AID-SMJ950>3.0.CO;2-K

Deardorff, A. V., \& Djankov, S. (2000). Knowledge transfer under subcontracting: Evidence from Czech firms. Research Seminar in International Economics, Discussion Paper No. 454. The University of Michigan, United State. https://doi.org/10.1016/S0305-750X(00)00060-7

Diallo, B. (2018). Bank efficiency and industry growth during financial crises. Economic Modelling, 68, 11-22. https://doi.org/10.1016/j.econmod.2017.03.011

Drake, L., Hall, M. J., \& Simper, R. (2006). The impact of macroeconomic and regulatory factors on bank efficiency: A nonparametric analysis of Hong Kong's banking system. Journal of Banking \& Finance, 30(5), 1443-1466. https://doi.org/10.1016/j.jbankfin.2005.03.022

Elloumi, F., \& Gueyie, J. P. (2001). Financial distress and corporate governance: an empirical analysis. Corporate Governance: The International Journal of Business in Society, 1(1), 15-23. https://doi.org/10.1108/14720700110389548

Faccio, M., Masulis, R. W., \& McConnell, J. (2006). Political connections and corporate bailouts. The Journal of Finance, 61(6), 2597-2635. https://doi.org/10.1111/j.1540-6261.2006.01000.x

Finkelstein, S., \& D’aveni, R. A. (1994). CEO duality as a doubleedged sword: How boards of directors balance entrenchment avoidance and unity of command. Academy of Management Journal, 37(5), 1079-1108. https://doi.org/10.5465/256667

Girardone, C., Molyneux, P., \& Gardener, E. P. M. (2004). Analysis the determinants of bank efficiency: The case of Italian banks. Journal of Applied Economics, 36(3), 215-227. https://doi.org/10.1080/0003684042000175334

Hajer, C., \& Anis, J. (2018). Analysis of the impact of governance on bank performance: case of commercial Tunisian banks. Journal of the Knowledge Economy, 9(3), 871-895. https://doi.org/10.1007/s13132-016-0376-6

Hajidimitriou, Y. A., Sklavounos, N. S., \& Rotsios, K. P. (2012). The impact of trust on knowledge transfer in international business systems. Journal of Economic and Sciences, 11(2), 39-49.

Hamori, M., \& Koyuncu, B. (2015). Experience matters? The impact of prior CEO experience on firm performance. Human Resource Management, 54(1), 23-44. https://doi.org/10.1002/hrm.21617

Hanafizadeh, P., \& Marjaie, S. (2019). Trends and turning points of banking: a timespan view. Review of Managerial Science, 1-37. https://doi.org/10.1007/s11846-019-00337-4

Harris, C. M., Pattie, M. W., \& McMahan, G. C. (2015). Advancement along a career path: the influence of human capital and performance. Human Resource Management Journal, 25(1), 102-115. https://doi.org/10.1111/1748-8583.12047 
Haynes, K. T., \& Hillman, A. (2010). The effect of board capital and CEO power on strategic change. Strategic Management Journal, 31(11), 1145-1163. https://doi.org/10.1002/smj.859

Hermalin, B. E., \& Weisbach, M. S. (2006). A framework for assessing corporate governance reform (No. w12050). National Bureau of Economic Research. https://doi.org/10.3386/w12050

Hillman, A. J., \& Dalziel, T. (2003). Boards of directors and firm performance: Integrating agency and resources dependence perspectives. Academy of Management Review, 28, 383-396. https://doi.org/10.5465/amr.2003.10196729

Hookway, J., \& Frangos, A. (2012, September 10). Vietnam loses glow as a market darling. The Wall Street Journal. http://www. wsj.com/articles/SB1000087239639044377940457764322008 9349912

Huhtala, J. P., Sihvonen, A., Frösén, J., Jaakkola, M., \& Tikkanen, H. (2014). Market orientation, innovation capability and business performance: Insights from the global financial crisis. Baltic Journal of Management, 9(2), 134-152. https://doi.org/10.1108/BJM-03-2013-0044

Jensen, M. C., \& Meckling, W. H. (1976). Theory of the firm, managerial behavior agency costs and ownership structure. Journal of Financial Economics, 3(4), 305-360. https://doi.org/10.1016/0304-405X(76)90026-X

Jeremias, J., \& Gani, L. (2013). The impact of board capital and board characteristics on firm performance. The British Accounting Review, 46(2), 135-153. https://doi.org/10.1016/j.bar.2013.12.001

Karamanou, I., \& Vafeas, N. (2005). The association between corporate boards, audit committees, and management earnings forecasts: An empirical analysis. Journal of Accounting Research, 43(3), 453-486.

https://doi.org/10.1111/j.1475-679X.2005.00177.x

Karlaftis, M. G. (2004). A DEA approach for evaluating the efficiency and effectiveness of urban transit systems. European Journal of Operational Research, 152(2), 354-364. https://doi.org/10.1016/S0377-2217(03)00029-8

Kauko, K. (2008). Manager and efficiency in banking. Journal of Banking and Finance, 33, 546-556. https://doi.org/10.1016/j.jbankfin.2008.09.007

Kim, T. H., Lee, J. N., Chun, J. U., \& Benbasat, I. (2014). Understanding the effect of knowledge management strategies on knowledge management performance: A contingency perspective. Information \& Management, 51(4), 398-416. https://doi.org/10.1016/j.im.2014.03.001

Lai, J. H., Chen, L. Y., \& Song, S. (2019). How outside directors' human and social capital create value for corporate international investments. Journal of World Business, 54(2), 93-106. https://doi.org/10.1016/j.jwb.2018.11.006

Lartey, V. C., Antwi, S., \& Boadi, E. K. (2013). The relationship between net interest margin and return on assets of listed banks in Ghana. Research Journal of Finance and Accounting, 4(6), 73-78.

Lee, W. C., \& Law, S. H. (2017). Roles of formal institutions and social capital in innovation activities: a cross-country analysis. Global Economic Review, 46(3), 203-231. https://doi.org/10.1080/1226508X.2017.1292859

Leightner, J. E., \& Lovell, C. K. (1998). The impact of financial liberalization on the performance of Thai banks. Journal of Economics and Business, 50(2), 115-131. https://doi.org/10.1016/S0148-6195(97)00073-8

Liao, S. H., Fei, W. C., \& Chen, C. C. (2007). Knowledge sharing, absorptive capacity, and innovation capability: an empirical study of Taiwan's knowledge-intensive industries. Journal of Information Science, 33(3), 340-359.

https://doi.org/10.1177/0165551506070739
Lin, Y. C., Wang, Y. C., Chiou, J. R., \& Huang, H. W. (2014). CEO characteristics and internal control quality. Corporate Governance: An International Review, 22(1), 24-42.

https://doi.org/10.1111/corg.12042

Lin, Z., Song, B. Y., \& Tian, Z. (2016). Does director-level reputation matter? Evidence from bank loan contracting. Journal of Banking \& Finance, 70(3), 160-176.

https://doi.org/10.1016/j.jbankfin.2016.04.021

Lopes de Melo, R. (2018). Firm wage differentials and labor market sorting: Reconciling theory and evidence. Journal of Political Economy, 126(1), 313-346. https://doi.org/10.1086/695505

Madison, K., Holt, D. T., Kellermanns, F. W., \& Ranft, A. L. (2016). Viewing family firm behavior and governance through the lens of agency and stewardship theories. Family Business Review, 29(1), 65-93.

https://doi.org/10.1177/0894486515594292

Maere, J. D., Jorissen, A., \& Uhlaner, L. M. (2014). Board capital and the downward spiral: Antecedents of bankruptcy in a sample of unlisted firms. Corporate Governance: An International Review, 22(5), 387-407.

https://doi.org/10.1111/corg.12078

Margaritis, D., \& Psillaki, M. (2007). Capital structure and firm efficiency. Journal of Business Finance \& Accounting, 34(9-10), 1447-1469. https://doi.org/10.1111/j.1468-5957.2007.02056.x

Marimuthu, M., Arokiasamy, L., \& Ismail, M. (2009). Human capital development and its impact on firm performance: Evidence from developmental economics. The Journal of International Social Research, 2(8), 265-272.

McDonald, M. L., Westphal, J. D., \& Graebner, M. E. (2008). What do they know? The effects of outside director acquisition experience on firm acquisition performance. Strategic Management Journal, 29(11), 1155-1177.

https://doi.org/10.1002/smj.704

Micheal, O. O., \& Zaid, A. A. (2014). An empirical analysis of human capital development and organizational performance in banking sector: A Nigerian experience. International Journal of Economics, Commercial and Management, 2(7), 1-15.

Miller, S. M., \& Noulas, A. G. (1996). The technical efficiency of large bank production. Journal of Banking \& Finance, 20(3), 495-509. https://doi.org/10.1016/0378-4266(95)00017-8

Moutsianas, K. A., \& Kosmidou, K. (2016). Bank earnings volatility in the UK: Does size matter? A comparison between commercial and investment banks. Research in International Business and Finance, 38, 137-150.

https://doi.org/10.1016/j.ribaf.2016.03.013

Mustapha, M. (2014). Monitoring costs of multinational companies: An agency theory perspective. Asian Journal of Business and Accounting, 7(2).

Muttakin, M. B., Khan, A., \& Mihret, D. G. (2018). The effect of board capital and CEO power on corporate social responsibility disclosures. Journal of Business Ethics, 150(1), 41-56. https://doi.org/10.1007/s10551-016-3105-y

Nickell, S. (1981). Biases in dynamic models with fixed effects. Econometrica: Journal of the Econometric Society, 14171426. https://doi.org/10.2307/1911408

Parham, S., \& Heling, G. W. J. (2015). The relationship between human capital efficiency and financial performance of Dutch production companies. Research Journal of Finance and Accounting, 6(8), 188-201.

Pedroni, P. (1996). Fully modified OLS for heterogeneous cointegrated panels and the case of purchasing power parity. Manuscript, Department of Economics, Indiana University, 5, 1-45.

Pesämaa, O., \& Franklin Hair Jr, J. (2007). More than friendship is required: An empirical test of cooperative firm strate- 
gies. Management Decision, 45(3), 602-615. https://doi.org/10.1108/00251740710745142

Pucheta-Martínez, M. C., \& Gallego-Álvarez, I. (2019). Do board characteristics drive firm performance? An international perspective. Review of Managerial Science, 1-47. https://doi.org/10.1007/s11846-019-00330-x

Reeb, D. M., \& Zhao, W. (2013). Director capital and corporate disclosure quality. Journal of Accounting and Public Policy, 32(4), 191-212.

https://doi.org/10.1016/j.jaccpubpol.2012.11.003

Rosenbusch, N., Brinckmann, J., \& Bausch, A. (2011). Is innovation always beneficial? A meta-analysis of the relationship between innovation and performance in SMEs. Journal of Business Venturing, 26(4), 441-457.

https://doi.org/10.1016/j.jbusvent.2009.12.002

Shahrier, N. A., Ho, J. S. Y., \& Gaur, S. S. (2018). Ownership concentration, board characteristics and firm performance among Shariah-compliant companies. Journal of Management and Governance, 1-24.

https://doi.org/10.1007/s10997-018-9436-6

Sharma, K. R., Leung, P., \& Zaleski, H. M. (1999). Technical, allocative and economic efficiencies in swine production in Hawaii: a comparison of parametric and nonparametric approaches. Agricultural Economics, 20(1), 23-35.

https://doi.org/10.1111/j.1574-0862.1999.tb00548.x

Shi, W., Connelly, B. L., \& Hoskisson, R. E. (2017). External corporate governance and financial fraud: cognitive evaluation theory insights on agency theory prescriptions. Strategic Management Journal, 38(6), 1268-1286. https://doi.org/10.1002/smj.2560

Silva, T. C., Guerra, S. M., Tabak, B. M., \& de Castro Miranda, R. C. (2016). Financial networks, bank efficiency and risktaking. Journal of Financial Stability, 25, 247-257. https://doi.org/10.1016/j.jfs.2016.04.004
Silva, T. C., Tabak, B. M., Cajueiro, D. O., \& Dias, M. V. B. (2017). A comparison of DEA and SFA using micro-and macro-level perspectives: Efficiency of Chinese local banks. Physica A: Statistical Mechanics and its Applications, 469, 216-223. https://doi.org/10.1016/j.physa.2016.11.041

Simsek, Z. (2007). CEO tenure and organizational performance: An intervening model. Strategic Management Journal, 28(6), 653-662. https://doi.org/10.1002/smj.599

Smith, M. S. (2008). Inter organizational knowledge transfer: Current themes and future prospects. Journal of Management Studies, 45(4), 677-690.

https://doi.org/10.1111/j.1467-6486.2008.00773.x

Sufian, F. (2007). The efficiency of Islamic banking industry in Malaysia. Journal of Banking and Finance, 23(3), 174-192. https://doi.org/10.1108/08288660710779399

Sufian, F. (2008). Determinants of bank efficiency during unstable macroeconomic environment: Empirical evidence from Malaysia. Journal of International Business and Finance, 23, 54-77. https://doi.org/10.1016/j.ribaf.2008.07.002

Sufian, F. (2009). Detreminants of bank efficiency during unstable macroeconomic environment: Empirical evidence from Malaysia. Research in International Business and Finance, 23, 54-77. https://doi.org/10.1016/j.ribaf.2008.07.002

Van der Sluis, J., Van Praag, M., \& Vijverberg, W. (2005). Entrepreneurship selection and performance: A meta-analysis of the impact of education in developing economies. The World Bank Economic Review, 19(2), 225-261. https://doi.org/10.1093/wber/lhi013

Wang, G., Oh, I. S., Courtright, S. H., \& Colbert, A. E. (2011). Transformational leadership and performance across criteria and levels: A meta-analytic review of 25 years of research. Group \& Organization Management, 36(2), 223-270. https://doi.org/10.1177/1059601111401017

\section{APPENDIX}

\section{Panel 1 List of Bank as Sample}

\begin{tabular}{|l|l|l|}
\hline Agribank & HSBC Bank & Shinhan Bank \\
\hline An Binh Bank & Kien Long Bank & Southern Asia Bank \\
\hline ANZ Bank & Lien Viet Post Commercial Bank & Standard Charter Bank \\
\hline Asia commercial Bank & Maritime Bank & Technical and Commercial Bank \\
\hline BACA Bank & Mekong Development Bank & Tienphong Bank \\
\hline Bao Viet Bank & MHB Bank & Viet Capital Bank \\
\hline BIDV Bank & Military Bank & Viet Nam Technological Bank \\
\hline Donga Bank & Nam A Bank & VietA Bank \\
\hline Eastern Asia Bank & Nam Viet Bank & Vietcom Bank \\
\hline Global Petro Bank & Ocean Bank & Vietin Bank \\
\hline Great Asia Bank & Orient Bank & Vietnam Export and Import Bank \\
\hline Great Trust Bank & Petrolimex Group Bank & Vietnam International Bank \\
\hline Hanoi Building Bank & Sai Gon Bank & Vietnam Prosperity Bank \\
\hline Hong Leong Bank & Sai GonThuong Tin Bank & Vietnam Thuong tin Bank \\
\hline House Development Bank & Saigon Hanoi Bank & Western Rural Bank \\
\hline
\end{tabular}

